\title{
Morphology and invitro Study of Chemicals, Plant Extracts, Bio-Agents against Pestalotiopsis mangiferae, Causing Grey Leaf Spot of Mango in Manipur, India
}

\author{
Ch. Inao Khaba*, Marjit Chandam, N. Ajitkumar Singh, \\ Ch. Premabati Devi and Bireswar Sinha
}
Department of Plant Pathology, College of Agriculture, CAU, Lamphelpat-795004, Manipur, India

*Corresponding author

\section{A B S T R A C T}

K e y w o r d s
Morphology,
Antagonists, Plant
extracts, Chemicals,
$\begin{aligned} & \text { P. mangiferae, } \\ & \text { Mango }\end{aligned}$
Article Info
$\begin{aligned} & \text { Accepted: } \\ & 18 \text { April } 2020 \\ & \text { Available Online: } \\ & \text { 10 May } 2020\end{aligned}$

A study was conducted in vitro condition to analyse the morphology and efficacy of bio agent, plant extract and some chemical against $P$. mangiferae that were collected from different districts of Manipur. The morphological character under study consists of colony and conidial characteristics such as colour, shape, size and appendages. The cultural growth colour of $P$. mangiferae on PDA differed from concolour to versicolour fuliginous. The conidial shape varied from oval and spherical to elliptical with prominent appendages. The conidial length and width were 22.9 and $5.7 \mu \mathrm{m}$ respectively. The diseased sample which was collected from different district of Manipur consists of three septation and the number of conidial appendages was found 2-3 numbers. Among seven antagonists namely Penicillium citrinum, Trichoderma atroviride, T. ovalisporum, Hypocrealixii, T. harzianum (69 \& 131) and T. asperellum evaluated in vitro, T. asperellum revealed the best in inhibiting the growth of the fungus $(85.8 \%)$. Among three plant extracts viz. garlic, neem and sweet flag evaluated in vitro, garlic extract $(3.0 \%)$ showed the best result (100.0\%). Among the seven chemicals viz. carbendazim, thiophenate methyl, mancozeb, imidacloprid, fipronil, profenophos and thiomethoxam evaluated in vitro, thiophenate methyl $(0.05 \%)$ and carbendazim $(0.05 \%)$ showed the best result with 100.0 per cent inhibition in fungal growth.

\section{Introduction}

Mangifera indica (Anacardiaceae) is one of the important fruit tree which is grown commercially both in tropical and subtropical region. Mango is known as king of fruits and it's a National fruit of India. The genus Mangifera originated in South-East Asia at an early date. Records suggest that it has been in cultivation in the Indian subcontinent for well over 4000 years now (De Candolle, 1904) and has been, since time immemorial, one of the most favourite of the kings and common people among fruits because of its delicious taste and fascinated flavour. According to Mukherjee (1958), the natural spread of genus is limited to the Indo-Malaysian region, extending from India to the Philippines and New Guinea in the east. India is the largest producer and contributing $40.75 \%$ of the total 
fruit production with 19.69 million tonnes production and 8.7 million tonnes/ha productivity (NHB, 2017). In India, the important states of mango producing viz. Andhra Pradesh, Bihar, Gujarat, Maharashtra, Odisha, Tamil Nadu, Karnataka, Uttar Pradesh and West Bengal. Apart from India, the other major producers of mango in the world are Brazil, Pakistan, Mexico, Indonesia, the Philippines, Haiti, China and Tanzania. Mango is also grown to a small extent in Egypt, Madagascar, Zaire, Venezuela and Sri Lanka. The climate condition of Manipur is well suited for growing of Mango.

Young and unripe mango, due to their acidic taste, are used for culinary purposes as well as for preparing pickles, chutneys and amchoor. Ripe fruits are used in preparing of squash, nectar, jam, cereal flakes, custard powder and baby food, mango leather (am-paper) and toffee. Moreover, fruits of some cultivars like Alphonso and Dashehari are sliced and canned for catering during the off-season.

Alphonso was found to be the most suitable for canned juice preparation due to its very good colour, Consistency and flavor, followed by Padiri (Gowdaand Ramanjaneya, 1995). The finest cultivars for processing were Haden, Haden 2H. Glenn, Joe Welch and Torbet, which had very good organoleptic characteristics (Donadio, 1995). High carotenoi content in Amrapali gives it potential for juice production and blending (Khurdiya and Roy, 1989).

The limiting factor in fruit yield is due to the occurrence of diseases. The pathogen (P.mangifera) causes infection on leaf, twigs and panicle. As a result the vegetative growth and the fruit production of young mango plants were reduced. In Manipur, grey spot of mango was first observed by Iboton \& Tombisana (2012) and little work on this disease was done by Indira (2014).

\section{Materials and Methods}

Surveys were conducted during September to November, 2017 on grey leaf spot of mango at different locations in the valley districts of Manipur namely Imphal East, Imphal West, Thoubal and Bishnupur (Plate 2). The diseased samples were brought to laboratory for isolation. The diseased samples were cut into small pieces of 2-3mm size.

These pieces were surface sterilized with $1 \%$ sodium hypochlorite solution for 2-3 minutes. The sterilized pieces were then inoculated on PDA Petri dish. The inoculated Petri plates were incubated at $28 \pm 1^{0} \mathrm{C}$ for 4 days. Daily observations were taken on the development of the pathogens. The fungal culture was purified by adopting hyphal tip cut method from the activity growing hyphal tips.

The pure culture was maintained on freshly prepared Potato Dextrose Agar slants inside the refrigerator and periodically sub cultured to fresh medium during the experimental period. Pathogenicity test was conducted by the method described by Koch (1876).

Per cent inhibition on growth was calculated which was described by Vincent (1927). The antagonistic activities was recorded by following dual culture technique using modified Bell's scale described by Bell et al., (1982) using PDA as basal medium.

\section{Results and Discussion}

The grey leaf spot of mango was found at various mango growing locations in different valley districts of Manipur (Table 1). Survey results indicated that there is prevalence of grey leaf spot of mango (plate 1) in Manipur, Rattan (2009) reported that grey blight of mango caused by P.mangiferae (P. Henn.) Stey is prevalent in many states in India. 


\section{Morphological study}

P.mangiferae was consistently isolated from the diseased samples of grey leaf spot of mango. The present findings is in agreement with those of Ko et al., (2007) who reported that single conidial isolates of the fungus were identified morphologically as $P$. mangiferae and were consistently isolated from the diseased mango leaves on PDA medium. Similarly, Keith and Zee (2010) who reported that Pestalotiopsis, Colletotrichum, Mucur and Guignardia were the agents of leaf spot of guava in Hawaii (Table 2 and Plate 2).

The conidial size of $P$. mangiferae ranged from 22.4-24.8 $\mu \mathrm{m}$ in length and 5.8-6.7 $\mu \mathrm{m}$ in width. The numbers of conidial appendages were found to be 2-3 in number. Cultural growth colour of $P$. mangiferae on PDA varied from concolour to versicolour fuliginous with varied shape such as oval and spherical to elliptical with prominent appendages. There was three septation in all the conidia collected from different places. Germ tube of the conidia at 8 hours ranged from 5.5-7.0 $\mu \mathrm{m}$, at 16 hours, $41.0-43.0 \mu \mathrm{m}$ and at 24 hours, 47.0-49.0 $\mu \mathrm{m}$ during incubation. The present finding is in agreement with the finding of S.K Singh (2011) who reported that Pestalotiopsis isolates were recorded with minor variations and homogenous conidial lengths (22.2 to $27.1 \mu \mathrm{m})$, conidial width $(5.5$ to $6.9 \mu \mathrm{m})$ and size of appendages ( 4.0 to $6.7 \mu \mathrm{m}$ ). However, three types of median colour cells were recorded among the isolates. Ranjana das et al., (2010) reported that the germination of spores started at 8 hours of incubation and gradually increased upto 20 hours (maximum).

\section{Pathogenecity test}

The fungus isolated from the diseased samples was found pathogenic when artificially inoculated on healthy excised leaves of mango could induced disease symptom after 7 days of incubation. On reisolation the same pathogen was found and thus proved pathogenecity of the pathogen (plate 3 \& 4). The present findings is in agreement with the findings of Ko et al., (2007) who reported that upon conducting pathogenecity tests, the symptoms of grey leaf spot were observed on all inoculated leaves, while uninoculated leaves remained completely free from symptoms. Reisolation from the inoculated leaves consistently yielded $P$. mangiferae.

\section{Efficacy of chemicals}

The linear growth of P.mangiferaewas completely inhibited by carbendazim $(0.1 \&$ $0.05 \%)$, thiophanate methyl $(0.1 \& 0.05 \%)$, and mancozeb at $0.1 \%$. However, mancozeb $(0.05 \%)$, Imidacloprid $(0.1 \%), \quad$ Fipronil $(0.2 \%)$, Profenophos $(0.1 \%)$ and Thiomethoxam $(0.1 \& 0.05 \%)$ showed 61.53 , $35.23,11.70,88.33$ and $(43.43 \& 17.57) \%$ inhibition over control respectively. Fipronil $(0.2 \%)$ showed the least inhibition of $11.70 \%$ on linear growth of the pathogen. The fungus failed to sporurate in all the fungicides tested. The inhibitory effect of thiophanate methyl and mancozeb on growth of fungus might be due to inhibition of nucleic acid synthesis, melanin synthesis and disrupting lipid metabolism while inhibitory effect of carbendazim might be due to disruption of enzyme synthesis, interfere with nuclear division of fungus. The present findings are in agreement with those of Kudalkar et al., (1991) who reported that growth and sporulation of $P$. mangiferae was completely inhibited in vitro by carbendazim (100$300 \mathrm{ppm}$ ). Mancozeb also inhibited growth by $78-86 \%$. Similar findings were also reported by Selvan et al., (1993) that Pestalotiopsis palmarum was completely inhibited under in vitro by Carbendazim and Thiophanate 
methyl at all concentrations tested. And also according to Rahman et al., (2013) who evaluated the efficacy of some selected contact, systemic and mixed fungicides against Pestalotia palmarum causal organism of grey spot of coconut (Table 3 and Plate 5).

\section{Antifungal properties of aqueous plant extracts}

Three plant extracts tested against mycelial growth of $P$. mangiferae, garlic extract $(3 \&$ $1.5 \%)$, neem extract $(10 \& 5 \%)$ and sweet flag extract $(10 \& 5 \%)$ could inhibit $(100 \&$ $77.76 \%),(82.35 \& 67.05 \%)$ and $(83.52 \&$ $61.17 \%)$ respectively. The effectiveness of garlic is might be due to antifungal activity of Diallyl-disuphide, Diallyl-trisulphide and ajoene (Table 4). The aqueous plant extracts under in vitro revealed that higher doses were relatively more efficient than the lower doses. The present findings are in agreement with the findings of Islam et al., (2004) who reported that among the plant extracts tested in vitro, garlic @3\% was most effective in inhibiting $100 \%$ radial growth of $P$. mangiferae (Plate 6).

Similarly, Saha et al., (2005) reported the antifungal properties of ethanol and aqueous extracts of Allium sativum (L.), Daturametel (L.), Dryopterisfilix-mas (L.) Schott, Zingiber officinale (Rosc.), Smilax zeylanica (L.), Azadirachtaindica, (A.) joss. And Curcuma longa (L.) on Pestalotiopsistheae (Saw.) and shown 100\% inhibition of spore germination.

Table.1 Survey of grey leaf spot of mango in Manipur

\begin{tabular}{|l|l|l|l|l|l|}
\hline & \multicolumn{3}{l|}{ Place of Survey } & GPS: LOCATION & \\
\hline SL.No & District & Site/Place & Latitude & Longitude & $\begin{array}{l}\text { Altitude } \\
\text { ft.) }\end{array}$ \\
\hline $\mathbf{1}$ & Imphal East & Andro KVK & $24^{\circ} 45.885$ & $094^{\circ} 03.274$ & 2649 \\
\hline $\mathbf{2}$ & Imphal East & Thayong & $24^{\circ} 47.828$ & $094^{\circ} 04.583$ & 2666 \\
\hline $\mathbf{3}$ & Imphal East & AndroMaringthel & $24^{\circ} 44.289$ & $094^{\circ} 01.097$ & 3335 \\
\hline $\mathbf{4}$ & Bishnupur & Nambol & $24^{\circ} 43.190$ & $094^{\circ} 50.153$ & 2537 \\
\hline $\mathbf{5}$ & Bishnupur & Ningthou-khong bazaar & $24^{\circ} 34.249$ & $094^{\circ} 45.829$ & 2510 \\
\hline $\mathbf{6}$ & Bishnupur & Potsangbam & $24^{\circ} 35.809$ & $094^{\circ} 45.940$ & 2560 \\
\hline $\mathbf{7}$ & Bishnupur & Utlou & $24^{\circ} 43.286$ & $094^{\circ} 51.538$ & 2538 \\
\hline $\mathbf{8}$ & Thoubal & Waithou & $24^{\circ} 40.326$ & $094^{\circ} 57.452$ & 2526 \\
\hline $\mathbf{9}$ & Thoubal & Kakchingsumangleikai & $24^{\circ} 29.791$ & $094^{\circ} 00.085$ & 2507 \\
\hline $\mathbf{1 0}$ & Thoubal & Wabagaimakhaleikai & $24^{\circ} 31.381$ & $094^{\circ} 56.107$ & 2498 \\
\hline $\mathbf{1 1}$ & Thoubal & Sekmaijingmakhaleikai & $24^{\circ} 33.256$ & $094^{\circ} 54.012$ & 2514 \\
\hline $\mathbf{1 2}$ & Imphal West & $\begin{array}{l}\text { Mayang } \\
\text { thanaawangleikai }\end{array}$ & $24^{\circ} 37.683$ & $094^{\circ} 53.532$ & 2489 \\
\hline $\mathbf{1 3}$ & Imphal West & $\begin{array}{l}\text { Hiyangthang mamang } \\
\text { leikai }\end{array}$ & $24^{\circ} 43.698$ & $094^{\circ} 54.372$ & 2518 \\
\hline $\mathbf{1 4}$ & Imphal West & Iroisemba & $24^{\circ} 45.161$ & $094^{\circ} 02.606$ & 2746 \\
\hline $\mathbf{1 5}$ & Imphal West & ICAR Lamphelpat & $24^{\circ} 49.651$ & $094^{\circ} 55.603$ & 2538 \\
\hline
\end{tabular}


Table.2 Morphological study of different isolates of $P$. mangiferae

\begin{tabular}{|c|c|c|c|c|c|c|}
\hline $\begin{array}{l}\text { Isolate of } \\
P . \text { mangiferae }\end{array}$ & $\begin{array}{l}* \text { Conidial } \\
\text { length }(\mu \mathrm{m})\end{array}$ & $\begin{array}{l}\text { *Conidialw } \\
\text { idth }(\mu \mathrm{m})\end{array}$ & $\begin{array}{l}\text { Number of } \\
\text { apical } \\
\text { appendages } \\
\text { (ranges) }\end{array}$ & $\begin{array}{l}\text { Type of median } \\
\text { colour }\end{array}$ & Shape & Septation \\
\hline 1. AndroKvk & $22.8 \pm 1.0$ & $6.8 \pm 0.9$ & $2-3$ & Concolour & $\begin{array}{l}\text { Oval with } \\
\text { prominent } \\
\text { appendages }\end{array}$ & 3 \\
\hline 2. Thayong & $24.8 \pm 0.6$ & $6.3 \pm 0.9$ & $2-3$ & $\begin{array}{l}\text { Versicolour } \\
\text { Fuliginous }\end{array}$ & $\begin{array}{l}\text { Spherical with } \\
\text { prominent } \\
\text { appendages }\end{array}$ & 3 \\
\hline 3. AndroMaringthel & $23.5 \pm 1.0$ & $6.2 \pm 0.7$ & $2-3$ & Concolour & $\begin{array}{l}\text { Oval with } \\
\text { prominent } \\
\text { appendages }\end{array}$ & 3 \\
\hline 4. Nambol & $24.9 \pm 0.8$ & $6.6 \pm 0.7$ & $2-3$ & $\begin{array}{l}\text { Versicolour } \\
\text { Fuliginous }\end{array}$ & $\begin{array}{l}\text { Elliptical with } \\
\text { prominent } \\
\text { appendages }\end{array}$ & 3 \\
\hline $\begin{array}{l}\text { 5. Ningthou-khong } \\
\text { bazaar }\end{array}$ & $22.9 \pm 1.0$ & $6.3 \pm 0.9$ & $2-3$ & Concolour & $\begin{array}{l}\text { Spherical } \\
\text { prominent } \\
\text { appendages }\end{array}$ & 3 \\
\hline 6. Potsangbam & $24.8 \pm 0.8$ & $6.3 \pm 0.9$ & $2-3$ & Concolour & $\begin{array}{l}\text { Oval with } \\
\text { prominent } \\
\text { appendages }\end{array}$ & 3 \\
\hline 7. Utlou & $23.4 \pm 1.0$ & $6.2 \pm 0.7$ & $2-3$ & $\begin{array}{l}\text { Versicolour } \\
\text { Fuliginous }\end{array}$ & $\begin{array}{l}\text { Elliptical } \\
\text { prominent } \\
\text { appendages }\end{array}$ & 3 \\
\hline 8. Waithou & $24.9 \pm 0.7$ & $6.3 \pm 0.8$ & $2-3$ & $\begin{array}{l}\text { Versicolour } \\
\text { Fuliginous }\end{array}$ & $\begin{array}{l}\text { Oval with } \\
\text { prominent } \\
\text { appendages }\end{array}$ & 3 \\
\hline $\begin{array}{l}\text { 9. Kakchingsu } \\
\text { mangleikai }\end{array}$ & $22.4 \pm 1.0$ & $5.7 \pm 0.9$ & $2-3$ & $\begin{array}{l}\text { Versicolour } \\
\text { Fuliginous }\end{array}$ & $\begin{array}{l}\text { Spherical with } \\
\text { prominent } \\
\text { appendages }\end{array}$ & 3 \\
\hline $\begin{array}{l}\text { 10. Wabagaima } \\
\text { khaleikai }\end{array}$ & $23.3 \pm 1.0$ & $6.2 \pm 0.4$ & $2-3$ & $\begin{array}{l}\text { Versicolour } \\
\text { Fuliginous }\end{array}$ & $\begin{array}{l}\text { Oval with } \\
\text { prominent } \\
\text { appendages }\end{array}$ & 3 \\
\hline $\begin{array}{l}11 . \\
\text { Sekmaijingmakhalei } \\
\text { kai }\end{array}$ & $22.8 \pm 1.0$ & $6.1 \pm 0.2$ & $2-3$ & $\begin{array}{l}\text { Versicolour } \\
\text { Fuliginous }\end{array}$ & $\begin{array}{l}\text { Elliptical with } \\
\text { prominent } \\
\text { appendages }\end{array}$ & 3 \\
\hline $\begin{array}{l}\text { 12. Mayang Imphal } \\
\text { thanaawangleikai }\end{array}$ & $23.9 \pm 0.8$ & $6.2 \pm 0.8$ & $2-3$ & Concolour & $\begin{array}{l}\text { Oval with } \\
\text { prominent } \\
\text { appendages }\end{array}$ & 3 \\
\hline $\begin{array}{l}\text { 13.Hiyangthang } \\
\text { mamang } \\
\text { leikai }\end{array}$ & $22.9 \pm 0.5$ & $5.4 \pm 0.8$ & $2-3$ & Concolour & $\begin{array}{l}\text { Elliptical with } \\
\text { prominent } \\
\text { appendages }\end{array}$ & 3 \\
\hline 14. Iroisemba & $24.2 \pm 0.2$ & $6.4 \pm 0.3$ & $2-3$ & $\begin{array}{l}\text { Versicolour } \\
\text { Fuliginous }\end{array}$ & $\begin{array}{l}\text { Oval with } \\
\text { prominent } \\
\text { appendages }\end{array}$ & 3 \\
\hline $\begin{array}{l}\text { 15. ICAR. } \\
\text { Lamphelpat }\end{array}$ & $23.9 \pm 0.8$ & $6.2 \pm 0.5$ & $2-3$ & Concolour & $\begin{array}{l}\text { Spherical with } \\
\text { prominent } \\
\text { appendages }\end{array}$ & 3 \\
\hline
\end{tabular}

*Mean of three replications 
Table.3 In vitro efficacy of chemicals on growth of $P$. mangiferae

\begin{tabular}{|l|l|c|c|}
\hline Sl. No. & Treatment & Concentration & $\begin{array}{c}\text { Inhibition (\%) } \\
\text { over control }\end{array}$ \\
\hline $\mathbf{1}$ & Carbendazim & $0.05 \%$ & $* 100$ \\
& & $0.1 \%$ & $100(89.50)$ \\
\hline $\mathbf{2}$ & Thiophenate methyl & $0.05 \%$ & $100(89.50)$ \\
\hline $\mathbf{3}$ & Mancozeb & $0.1 \%$ & $100(89.50)$ \\
\hline & & $0.05 \%$ & $100(89.50)$ \\
\hline $\mathbf{4}$ & Thiomethoxam & $0.1 \%$ & 15.29 \\
& & $0.05 \%$ & $(51.99)$ \\
\hline & & $0.1 \%$ & 17.56 \\
& & & $436.36)$ \\
\hline $\mathbf{5}$ & Imidacloprid & $0.1 \%$ & $(20.03)$ \\
\hline $\mathbf{6}$ & & & 35.23 \\
& Fipronil & $0.2 \%$ & $(70.38)$ \\
\hline $\mathbf{7}$ & Profenophos & & 11.70 \\
& & $0.1 \%$ & $(41.27)$ \\
\hline & SE (d) \pm & & 88.33 \\
\hline & CD(0.05) & & $(46.67)$ \\
\hline
\end{tabular}

*Mean of three replication

**Figures in parenthesis are arcsine transformed value

Table.4 Effect of plant extracts on the growth of P. mangiferae in vitro

\begin{tabular}{|l|l|c|c|}
\hline Treatment & Plant part used & Concentration \% & $\begin{array}{c}\text { Inhibition \% over } \\
\text { control }\end{array}$ \\
\hline Garlic & Clove & 1.5 & $\begin{array}{c}* 71.76 \\
* *(89.32)\end{array}$ \\
& & & 100.00 \\
& & 3 & $(57.90)$ \\
\hline Neem & Leaf & 5 & 67.05 \\
& & 10 & $(65.16)$ \\
& & & 82.35 \\
& & 5 & $(56.30)$ \\
\hline Sweet flag & Rhizome & & 61.17 \\
& & 10 & $(66.06)$ \\
\hline SE(d) & & & 83.52 \\
\hline CD & & & $(51.45)$ \\
\hline
\end{tabular}

* = Mean of three replications

**Figures in parenthesis are arcsine transformed value 
Table.5 Effect of bio control agents on the growth of $P$. mangiferae in vitro

\begin{tabular}{|c|c|c|c|c|}
\hline SL. No. & Biocontrol agent & $\begin{array}{l}\text { Duration point } \\
\text { of contact(days) }\end{array}$ & Bell's scale & $\begin{array}{c}\text { Inhibition over } \\
\text { control }(\%)\end{array}$ \\
\hline 1 & Penicillium citrinum & - & Class iv & $\begin{array}{c}* 47.52 \\
* *(43.53)\end{array}$ \\
\hline 2 & $\begin{array}{l}\text { Trichoderma harzianum } \\
\text { (KU933468) }\end{array}$ & 2 & Class i & $\begin{array}{r}63.17 \\
(52.62 \\
\end{array}$ \\
\hline 3 & $\begin{array}{l}\text { T. harzianum } \\
\text { (KU933474) }\end{array}$ & 2 & Class i & $\begin{array}{c}64.00 \\
(53.08)\end{array}$ \\
\hline 4 & $\begin{array}{l}\text { T. ovalisporum } \\
\text { (KU904456) }\end{array}$ & 3 & Class vi & $\begin{array}{c}74.58 \\
(59.68)\end{array}$ \\
\hline 5 & $\begin{array}{l}\text { T. hypocrea } \\
\text { (KX0113223) }\end{array}$ & 3 & Class vi & $\begin{array}{c}60.47 \\
(49.07)\end{array}$ \\
\hline 6 & $\begin{array}{l}\text { T. asperellum } \\
\text { (KU933475) }\end{array}$ & 3 & Class i & $\begin{array}{c}85.88 \\
(67.93)\end{array}$ \\
\hline 7 & $\begin{array}{l}\text { T. atroviride } \\
\text { (KU933472) }\end{array}$ & 2 & Class i & $\begin{array}{c}84.00 \\
(66.35)\end{array}$ \\
\hline \multicolumn{2}{|l|}{$\mathrm{SE}(\mathrm{d})$} & & & 2.57 \\
\hline \multicolumn{2}{|l|}{$\mathrm{CD}_{(0.05)}$} & & & 5.53 \\
\hline
\end{tabular}

*Mean of three replications

**Figures in parenthesis are arcsine transformed value
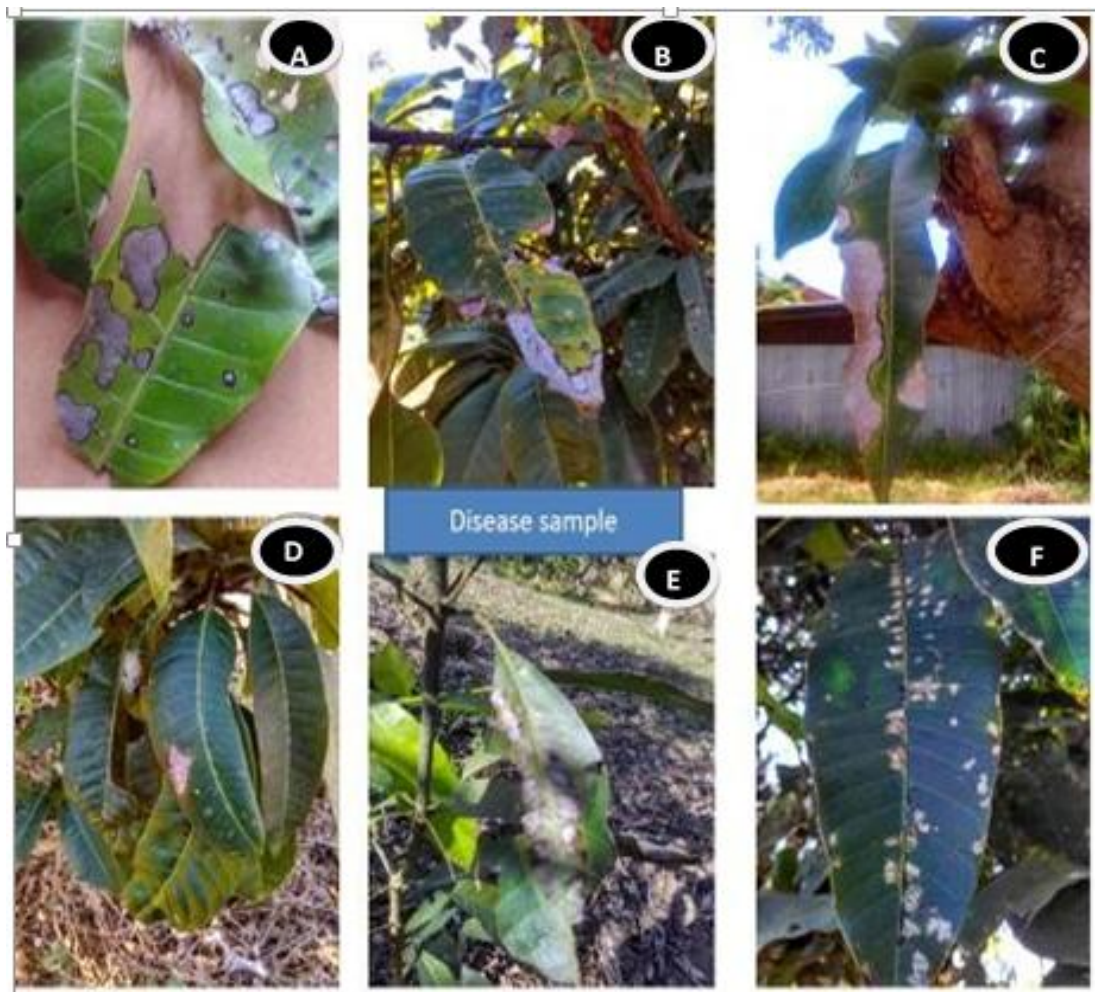

Plate.1 Symptoms of grey leaf spot of mango from different areas of Manipur A=Imphal West, $\mathrm{B}=$ Imphal East, $\mathrm{C} \& \mathrm{D}=$ Thoubal and $\mathrm{E} \& \mathrm{~F}=\mathrm{Bishnupur}$ 


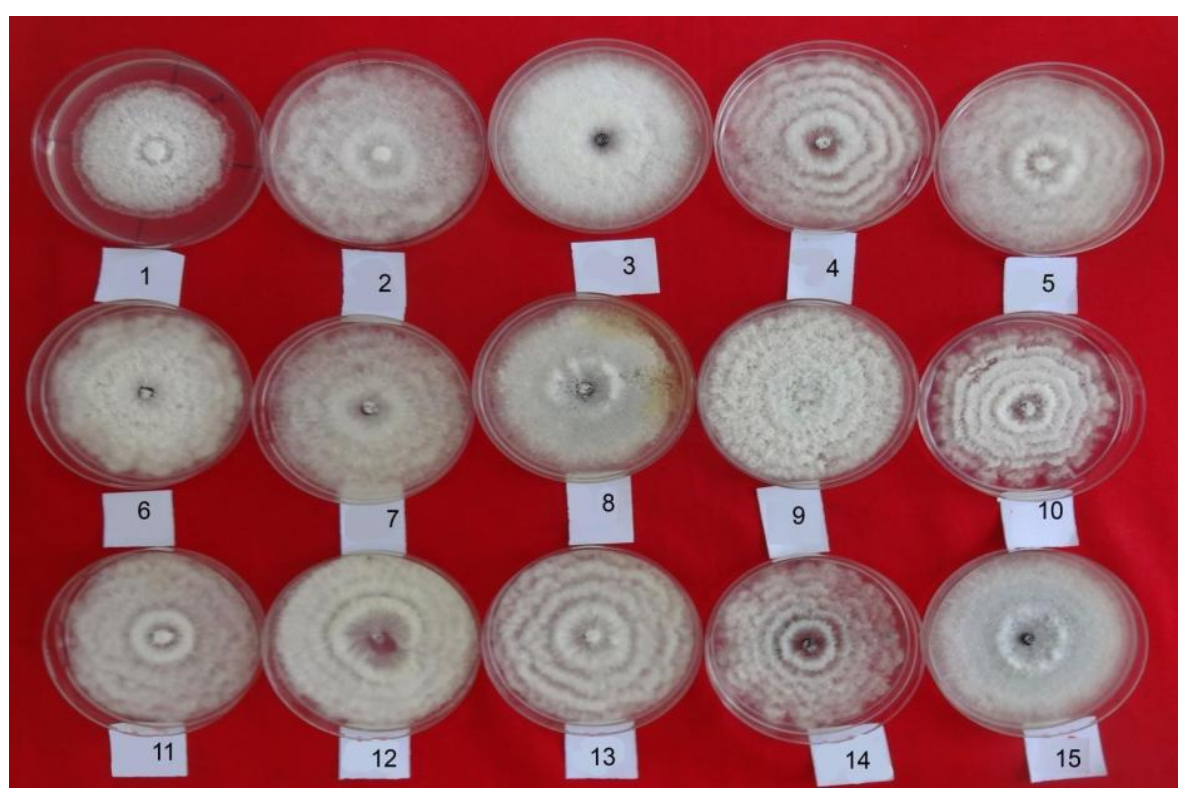

Plate.2 Different isolates of P. mangiferae (1=Andro KVK, 2=Thayong, 3=AndroMaringthel, 4=Nambol, 5=Ningthoukhong, 6=Potsangbam, 7=Utlou, 8=Waithou, 9=Kakching, 10=Wabagai, 11=Sekmaijing, 12=Mayang Imphal, 13=Hiyangthang, 14=Iroisemba, 15=ICAR Lamphelpat)

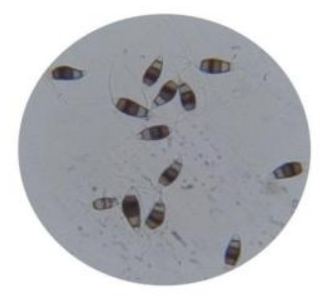

1

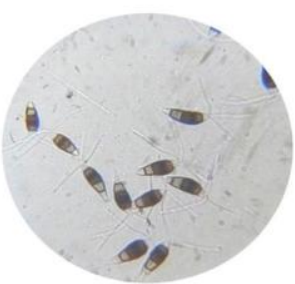

4

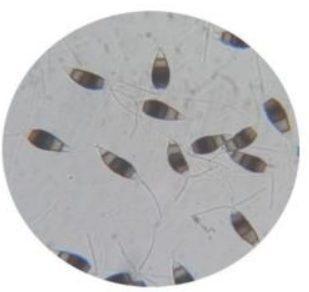

2

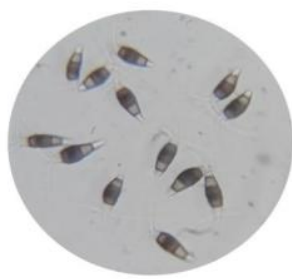

4

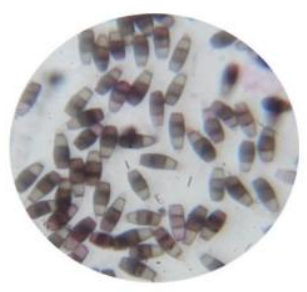

3

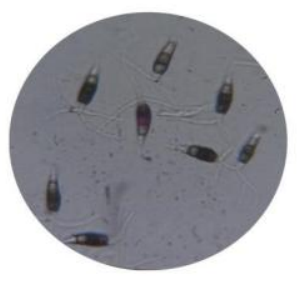

5

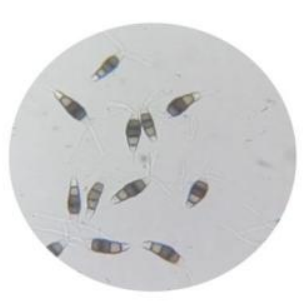

7

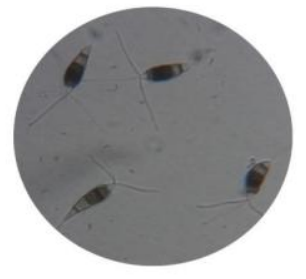

8

Plate.3(A) Conidia of different isolates of $P$. mangiferae ( $1=$ Andro KVK, $2=$ Thayong, 3=AndroMaringthel, 4=Nambol, 5=Ninthoukhong, 6=Potsangbam, 7=Utlou, 8=Waithou) 


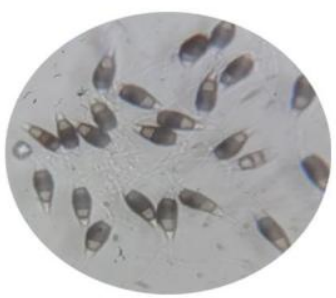

9

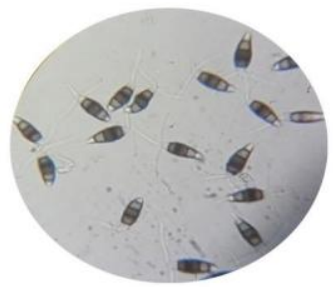

12

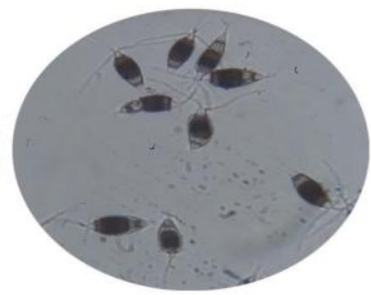

10

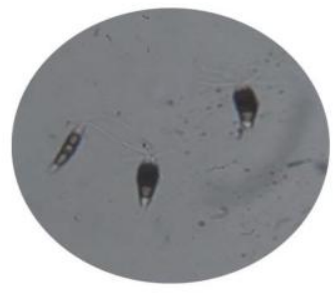

13

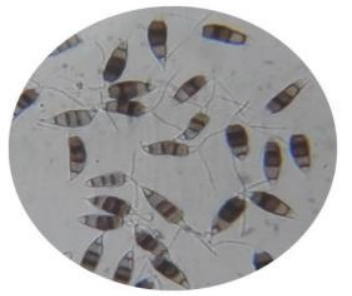

15

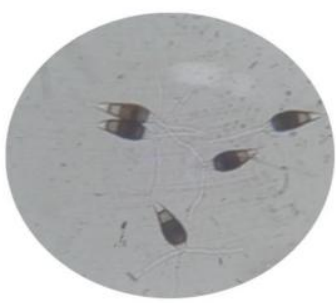

11

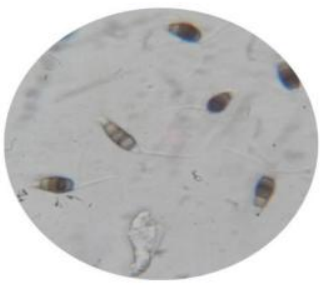

14

Plate.3(B) Conidia of different isolates of $P$. mangiferae $(9=$ Kakching $10=W a b a g a i$, 11=Sekmaijing, 12=Mayang Imphal, 13=Hiyangthang, 14=Iroisemba, 15=ICAR Lamphelpat)
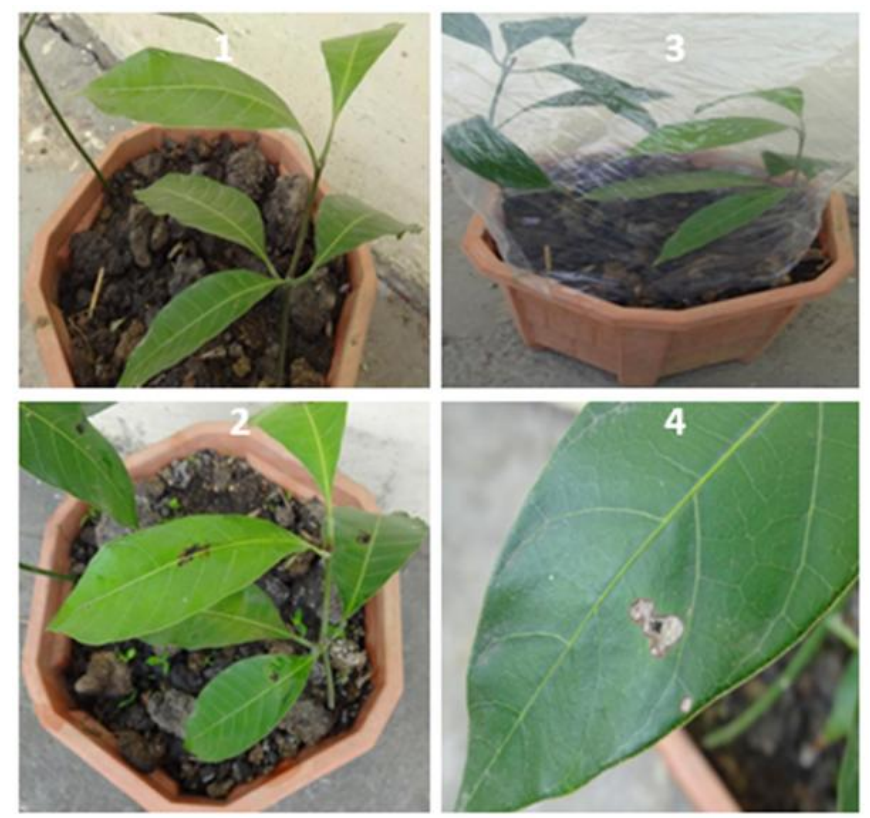

Plate.4 Pathogenecity test of P. mangiferae (Stepwise, 1-4) 


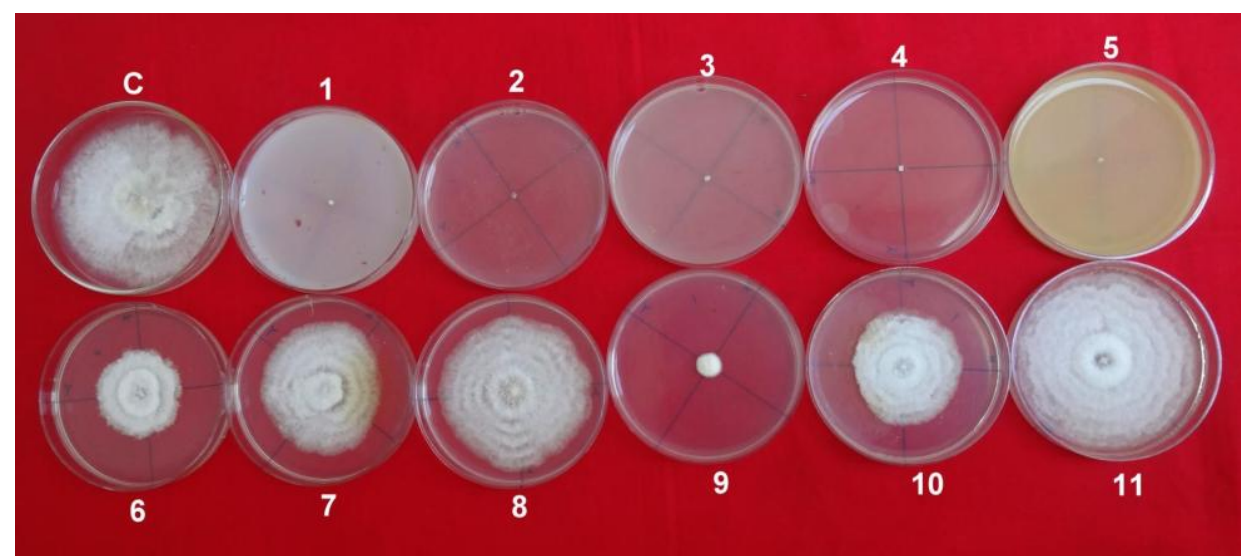

Plate.5 In vitro efficacy of chemicals on growth of $P$. mangiferae $(\mathrm{C}=\mathrm{Control}, 1=$ Carbendazim $0.1 \%, 2=$ Carbendazim $0.05 \%, 3=$ Thiophenate methyl $0.1 \%, 4=$ Thiophenate methyl $0.05 \%$, 5=Mancozeb 0.1\%, 6=Mancozeb 0.05\%, 7=Imidacloprid 0.1\%, 8=Fipronil 0.2\%, 9=Profenophos $0.1 \%, 10=$ Thiomethoxam $0.1 \%, 11=$ Thiomethoxam 0.05 )

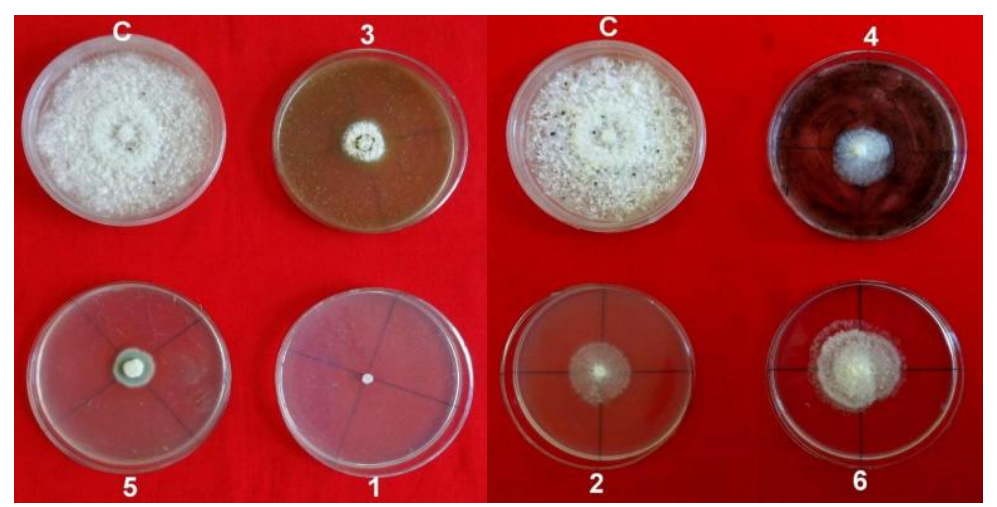

Plate.6 Effect of plant extracts on the growth of $P$. mangiferae [C=Control, $1=$ Garlic (3\%), $2=$ Garlic $(1.5 \%), 3=$ Neem $(10 \%), 4=$ Neem (5\%), 5=Sweet flag (10\%), 6=Sweet flag (5\%)]

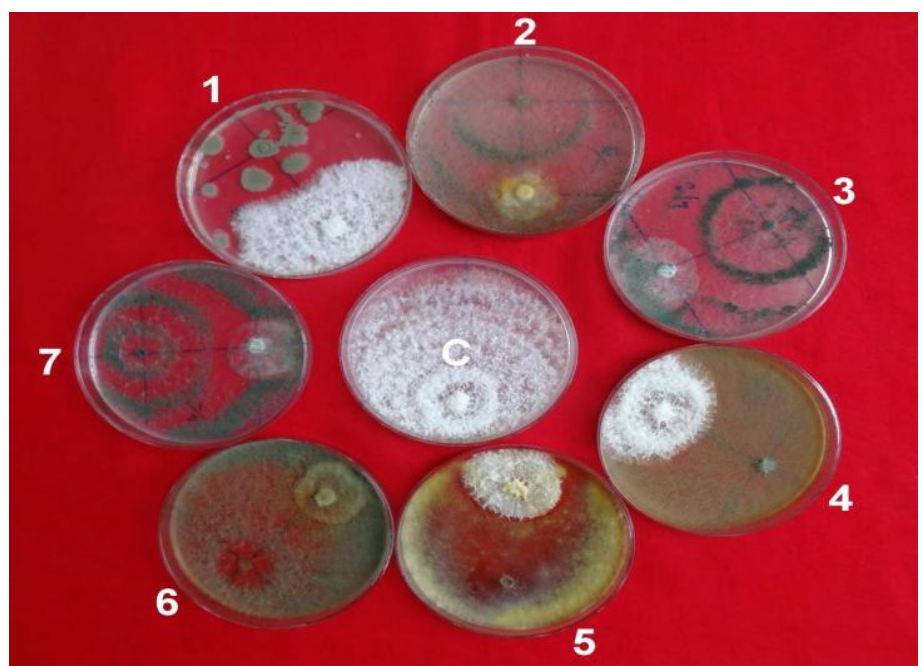

Plate.7 Effect of bio control agents on the growth of $P$. mangiferae $(\mathrm{C}=$ Control $1=$ Penicillium citrinum, 2=Trichoderma harzianum (KU933468), 3=T. harzianum (KU933474), 4=T. ovalisporum, $5=T$. hypocrea, $6=T$. asperellum, $7=T$. atroviride) 


\section{Effect of biocontrol agents}

Findings revealed that three species of Trichoderma could come in contact with the pathogenic fungus after 2 days of incubation. $P$. mangiferae was overgrown by $100 \%$ (Class I) by the antagonists $T$. harzianum 69, T.harzianum 131, T. asperellum 7 and T.atroviride. Penicillium citrinum remained locked with the fungus at the point of contact (Class IV). However, the antagonists $T$. ovalisporum and $T$. hypocrea could not overgrow the fungus but formed inhibition zone of $2.16 \mathrm{~cm}$ and $3.36 \mathrm{~cm}$ (ClassVI). The present findings are in agreement with those of Bhuvaneswari and Rao (2001) who reported that $T$. viride could inhibit $72.88 \%$ on the growth of Pestalotia sp. Similarly, Bhargava et al., (2003) also reported that T.harzianum could inhibit the mycelial growth of P.dessiminata. The antagonistic effects of species of Trichoderma against pathogen might be due to (a) production of non-volatile toxic substances diffuse in the substrate and (b) parasitism of the antagonists. The formation of inhibition zone indicates the production of antibiotics by the antagonists which diffused in the medium (Table 5 and Plate 7).

The fungus causing grey leaf spot of mango was well distributed in all localities in different districts of Manipur. The severity of disease was found highest from late September to November, 2017. Among all the treatments, fungicides (thiophanate methyl and carbendazim) were most effective which was closely followed by plant extract (garlic extract) and bio control agent (T. harzianum). Even though fungicides were very effective, they are considered harmful to human health and detrimental effect on environment.

As a substitute of fungicides, effective plant extracts or bio control agents could be used as one of components of integrated disease management. The increased in protein synthesis in plant attacked by pathogen reflects the increased production of enzymes and other protein involved in defence reactions of the plant. Therefore, timely application of management practices will increased the resistant capacity of the plant which will be directly proportional to plant yield. These findings will be greatly helpful to the mango farming community in Manipur. Hence, further research work on the epidemiology, its survival and spread may be taken up for reducing the incidence of disease.

\section{References}

Bell, D.K., Wells, H.D. and Markham, C.R. (1982). In vitro antagonism of Trichoderma spp. against six fungal plant pathogens. Phytopathol., 72: 379382.

Bhargava, A.K., Sobti, A.K. and Ghasolia, R.P. (2003). Studies on guava (Psidium guajava L.) drying/wilt disease in orchards of Pushkar valley. J. Phytol. Res., 1(1): 81-84.

Bhuvaneswari, V. and Rao, M.S. (2001). Evaluation of Trichoderma viride antagonistic to postharvest pathogens on mango. Indian Phytopathol., 54(4): 493-494.

De Candolle. (1904). Origin of cultivated plants, Kegan Paul London.

Devi, M.I. (2014). Grey leaf spot of Mango and its management. MSc (Agri.) Thesis, Submitted to Central Agricultural University, Imphal. pp136.

Das Ranjana, Chutia M., Das K. and Jha D.K. (2010). Factors affecting sporulation of $P$. dissemination causing grey blight disease of Persea bombycina host. The primary food plant of muga silkworm. Crop protect., 29: 963-968.

Donadio, L.C. (1995) ActaHortic., 379:137- 
140.

Gowda, I.N.D. and Ramanjaneya, K.H. (1995). J. Food Sci. Tech., 32:323-325.

Islam, M.R., Hossain, M.K., Bahar, M.H. and Ali, M.R. (2004). Identification of the causal agent of leaf spot of betel nut and in vitro evaluation of fungicides and plant extracts against it. Pakistan J. Biol. Sc., 7(10): 1758-1761.

Keith, L.M. and Zee, F.T. (2010). Guava diseases in Hawaii and the characterization of Pestalotiopsis spp. affecting guava. ActaHortic., 894: 296276.

Khurdiya, D.S. and Roy, S.K. (1989). ActaHortic., 231: 709-714.

Ko,Y., Yao, K.S., Chen, C.Y. and Lin, C.Y. (2007). First report of grey leaf spot of mango (Mangifera indica) caused by Pestalotiopsis mangiferae in Taiwan. Plant Dis., 91(12): 1684.

Koch, R. (1876). In: Agrios GN (ed) Plant Pathology. $5^{\text {th }}$ edn. Academic Press, San Diego, California, pp. 26-27.

Kudalkar, S.R., Joshi, M.S. and Pawar, D.R. (1991). Control of leaf blight of coconut caused by Pestalotia palmarum. Indian Coconut J., 22(3):18-19.

Mukherjee, S.K. (1958). The origin of mango. Indian J. hortic., 15: 129-34

National Horticulture Board (2016). Indian
Horticultural Database. Ministry of Agriculture Government of India 85, Institutional Area, Sector-18, Gurgaon122015, India

Rahman, S., Adhikary, S.K., Sultana, S., Yesmin, S. and Jahan, N. (2013). In vitro evaluation of some selected fungicides against Pestalotia palmarum (cooke) causal agent of grey leaf spot of coconut. J. Plant Pathol. Microbiol., 4(9): 197.

Rattan, G.S. and Singh, P. (2009). Evaluation of fungicides against the leaf spot of eucalyptus, mulberry and jamun in nursery. Plant Dis. Res., 24: 89-90.

Saha, D., Dasgupta, S. and Saha, L. (2005). Antifungal activity of some plant extracts against fungal pathogens of tea (Camellia sinensis). Pharm. Biol., 43(1): 87-91.

Singh, N.I. and Devi, R.K.T. (2012). Departmental survey report on Horticultural crops. Pp1-2.

Verma, K.S. and Singh, T. (1996). Prevalence of grey blight of mango caused by Pestalotiopsis mangiferae. Plant Dis. Res., 11(1): 69-71.

Vincent, J.M. (1927). Distortion of fungal hyphae in presence of certain inhibitors. Nature, 159: 850.

\section{How to cite this article:}

Ch. Inao Khaba, Marjit Chandam, N. Ajitkumar Singh, Ch. Premabati Devi and Bireswar Sinha. 2020. Morphology and Invitro Study of Chemicals, Plant Extracts, Bio-Agents against Pestalotiopsis mangiferae, Causing Grey Leaf Spot of Mango in Manipur, India. Int.J.Curr.Microbiol.App.Sci. 9(05): 2411-2422. doi: https://doi.org/10.20546/ijcmas.2020.905.275 